Article

\title{
Migration Regimes and the Translation of Human Rights: On the Struggles for Recognition of Romani Migrants in Germany
}

\author{
Jure Leko \\ Käte Hamburger Center for Advanced Study in the Humanities “Law as Culture”, University of Bonn, 53227 Bonn, Germany; \\ E-Mail: jureleko@uni-bonn.de
}

Submitted: 31 January 2017 | Accepted: 31 July 2017 | Published: 19 September 2017

\begin{abstract}
The current claims for asylum and refugee protection of Roma from the so-called "Western Balkan states" are rejected by the German state. Based on this practice, Romani migrants are not recognized as genuine refugees but classified as irregular migrants and thus labeled as "bogus" asylum seekers. This article discusses the discursive process through which the legal status of Romani migrants is irregularized within the German migration regime. Furthermore, through an empirical study, the article shows how Romani organizations and migrants are struggling for a collective right to remain in Germany. In their political-legal struggles for recognition, Roma reinterpret not only their legal status as irregular migrants, but also their legal-cultural practices: by appropriating the semantics of human rights through the lenses of their cultural backgrounds. This, in turn, shifts the analytical focus to the productivity of human rights discourses. They are assumed to be an effective tool to enforce legal claims against the German migration regime. In this context, the article examines legal-cultural practices, which become visible in the struggle, by exploring six justification narratives-through these, the Roma's political-legal belonging to the German nation-state shall be legitimized.
\end{abstract}

\section{Keywords}

asylum; human rights; migration; migration regime; refugee; Roma

\section{Issue}

This article is part of the issue "Perspectives on the European Border Regime: Mobilization, Contestation, and the Role of Civil Society", edited by Ove Sutter and Eva Youkhana (University of Bonn, Germany).

(C) 2017 by the author; licensee Cogitatio (Lisbon, Portugal). This article is licensed under a Creative Commons Attribution 4.0 International License (CC BY).

\section{Introduction}

While the number of Roma ${ }^{1}$ from the so-called Western Balkans $^{2}$ who migrated to Germany has sunken since the end of the wars in Croatia and Bosnia and Herzegovina as well as the Kosovo War, figures have been continually rising since 2008, with 2015 presenting the peak of the development for the time being (Alscher, Obergfell, \& Roos, 2015; Heuser, 2014; Wenke, Jadžić, \& Jeremić, 2016). The reasons for the current migration vary de- pending on political context and individual fate; beyond all differences, Roma's motivations for migrating rest particularly on the fact that they became the "losers" after the collapse of Yugoslavia, which manifests in everyday practice in the form of diverse human rights violations (Sardelić, 2014). Since 2009, however, a process of visa liberalization, which has made it easier for Western Balkan citizens to obtain valid emigration paperwork, has been reinforcing the current migration (Cherkezova, 2014, p. 5).

\footnotetext{
${ }^{1}$ In the European context, Roma is both an ethnic self-representation and depicts a politically enforced umbrella term for diverse, heterogeneous subgroups. In the latter case, this term includes - next to Roma - the Sinti, Kale, Manush, and related groups-although it cannot always be assumed that individual members of the respective groups approve of this political convention of speech (Knecht \& Toivanen, 2006). The term "Roma" is used particularly as an umbrella term in the first part of the article because it appears as such in the sources used; however, I employ this in my own empirical analysis as a self-description for people from the Western Balkans and those who label themselves as such, for instance, in public or before authorities, and, in this context, differentiate themselves from other subgroups. According to Hancock (2002, p. xix), I use the term "Romani" as an adjective. I only use the often pejoratively found and politically discredited term "gypsy" (Knecht \& Toivanen, 2006) when it appears as such in the sources used.

2 The so-called "Western Balkans" is a relatively new political umbrella term that, next to the successor states of former Yugoslavia (excluding Slovenia), also includes Albania.
} 
This development is embedded in the EU integration process of Western Balkan states which prioritizes the protection of minorities. This, in turn, accompanies the fact that it is in the interest of the respective governments not only to accept Roma deported from Germany as well as from other European member states, but also to prevent the migration of potential asylum seekers so that they do not lose credibility as possible EU Member State candidates (Flüchtlingsrat NRW, 2012). At the same time, a desired "side effect" of the Europeanization of the Western Balkan countries was to tame and control the migration of Roma, by which the "Roma question" became an aspect of securitization within the German and European migration regime (Kacarska, 2012; van Baar, 2011b). Nevertheless, for many Roma, applying for asylum or refugee protection after arriving in Germany presents a chance to escape diverse forms of discrimination. The German government does not view Roma's protection claims as being worthy of recognition, as they are usually neither politically persecuted nor fleeing from war and thus fail to meet the criteria for German asylum and refugee protection. Instead, German authorities are irregularizing the Romani migrant status and classifying them as "economic" or "poverty" migrants (Sardelić, 2016; Scherr, 2015a). ${ }^{3}$

Against this background, a clearly visible Romani protest movement, which fights for a collective right of residence that employs human rights in order to disrupt Roma's history of infringement, at least in regard to refugee law, began forming around 2008. The shared fundamental attitude is that a structural discrimination against Roma dominates in the Western Balkans and that the present asylum and refugee protection should be extended to include them. ${ }^{4}$

This article has two main goals: Firstly, it aims to depict Roma's current migration from the Western Balkans within European policy at present, and subsequently reveal through which practices they are categorized as "bogus asylum seekers" in legal and political discourse as well as in the media (Kacarska, 2012; Lee, 2014; Sardelić, 2016). By using selected examples, I sketch which role Western Balkan governments play within the German as well as European migration regime. ${ }^{5}$ Secondly, based on my own empirical study, the article attempts to illustrate legalcultural practices, which become visible in the struggle for recognition, by illustrating six justification narratives. ${ }^{6}$

In the following, I first detail the article's theoretical framework (2.) and continue by elaborating on my methodological approach (3.). The analysis then begins with an outline of the current human rights situation of Roma from the Western Balkans (4.). Building on this and within the context of the European Union, a closer look is taken at the German migration regime, which, by utilizing various border practices, tries to categorize and control the migration movement as well as include it in its political economy (5.). Subsequently, I offer the general results of my field research by presenting an in-depth overview of the central justification narratives used to enforce the right to political-legal belonging (6.). Lastly, by way of an example, namely the occupation of the Sinti and Roma Memorial in Berlin, I illustrate how the translation and appropriation of human rights can tangibly take place as well as how selected justification narratives are staged and which social effects can result therefrom (7.).

\section{Theoretical Orientations: Migration Regimes, Translation of Human Rights, and Law as Culture}

The present article is based on a theoretical perspective that relates migration regimes, translation theory, and law-as-culture analytics. The concept "regime" has proven to be extremely fruitful when trying to adequately understand discursive practices of legal inclusion and exclusion as well as forms of border control and legal categorization of migrants. Karakayali and Tsianos (2007, p. 14) consider a regime:

An ensemble of social practices and structures - discourses, subjects, state practices-the arrangement of which is not determined from the outset, but rather consists precisely in [generating] answers to questions and problems [stemming from] the dynamic elements and processes..." (own translation)

Based on this definition, a migration regime can be considered institutionalized practices and structures in which principles, norms, and legal conceptions concerning how to address migration are defined and "the actors installing it accept as an objective set of rules for a certain period" (Hess \& Karakayali, 2007, p. 48, own translation).

Accordingly, the categorization of migrants can be understood as a contingent process, whereby determining the difference between "legalized" and "irregularized" migrant status is carried out through social struggles. However, according to the regime perspective, it is not a state's legislative, judicial, and executive branches

\footnotetext{
${ }^{3}$ From a sociological/anthropological perspective it is not possible to determine who is a poverty migrant and who is a refugee. As this differentiation occurs in political and legal negotiation processes, the analytical task is rather to show how this differentiation takes place in political-legal practice and which alternative definitions exist. Cf. Scherr (2015a).

${ }^{4}$ Comments on the protest movement are based on my own field studies that I conducted while completing my doctoral thesis. For more on the empirical approach, see Chapter 3 (Methodological Framework).

${ }^{5}$ In this article, I present on the one hand a general overview of the human rights situation of Roma in the Western Balkans; concrete examples, on the other hand, focus especially on Serbia and Macedonia as well as occasionally on Kosovo.

${ }^{6}$ Several works on this thematic field do admittedly exist, however, not in the presented synopsis and German context. For instance, in their insightful works, Sardelić (2016) and Çağlar and Mehling (2013) also address the question of how Romani migrants try to achieve political belonging via acts of citizenship. In contrast to their particularly normative perspective, this article does not explore the citizenship debate in such detail, but instead more deeply reveals the cultural modus operandi of appropriation and translation of universal norms (human rights). On general debates about struggles for recognition and human rights in relationship to Roma, see Tremlett, McGarry and Agarin (2014) and Sigona and Trehan (2009).
} 
alone that are involved in the struggles, but also a multitude of actors operating at various levels that interact with each other: from supranational institutions (such as the EU, UNHCR) to NGOs and the media to civil society and migrants themselves (Müller, 2010, p. 26).

Following Benhabib (2004), I assume that the conflict surrounding the recognition of rights for migrants ignites at the central contradiction within democratic states: namely that between national self-determination and the preservation of human rights. By making strategic use of human rights and attempting to exert normative pressure on state institutions in the process, Roma and their representatives also subjectify human rights semantics with the aim of renegotiating the relationship between national interests and universal human rights, thus posing the question of legal affiliation anew.

The productivity of human rights therefore moves into the focus of analysis, whereby the Geneva Convention on Refugees and asylum law are to be understood as a segment of the international human rights regime (Benhabib, 2004, p. 7ff). However, their potential only unfolds when they are translated into concrete practice complexes and appropriated there. Following Renn (2010), I assume that this appropriation is not a seamless process of translation, but rather one riddled with numerous shifts in meaning, as human rights must pass through different application filters. A translation is successful when a normative linkage of meaning is formed between two or more sub-contexts. Roma, together with refugee organizations, initiatives, networks, and experts, play a crucial role in coordinating the struggles over the right of residence, for they form, to put it in a simplified manner, the interfaces between political-legal decision makers and the affected persons. Through their accumulated knowledge and material resources, they have the potential to successfully translate human rights claims into the political-legal field (Göhlich, Nekula, \& Renn, 2014, p. 9ff).

In order to present the modus operandi in which Roma appropriate certain human rights semantics in light of their cultural knowledge and respectively intertwine legal codes with cultural presuppositions, I refer to Gephart's (2015) "law-as-culture analytics". With the help of his analytics, it is first possible to disengage the legal concept of a strictly codified understanding and open it up to a multidimensional perspective in order to capture (general) notions of norms not fixed by the state. In the context of this article, the protest movement as well as Roma involved in it not only claim human rights as codified in asylum and refugee law, but likewise produce new rights in the course of cultural appropriation and reinterpretation of human rights codes and then retranslate them into the political-legal field (Stammers, 2009). Beyond conventional legal analysis, an adequate investigation of legal-cultural practices, moreover, requires a concept of law in which the focus is not only on the purely (juridical-) normative aspects. By including symbolic (Gephart, 2015) and narrative (Suntrup, 2013) di- mensions in addition to a normative dimension in the analysis of the struggle for recognition, I would not only like to demonstrate how normative claims of validity ( $\mathrm{Gel}$ tungsansprüche) are derived by seizing (historical) symbols and justification narratives, but also how the representation of cultural knowledge is intertwined with universal codes of human rights.

\section{Methodological Framework}

As the analysis of discourses, collective knowledge, and practices takes a central position in this article, the "sociology of knowledge approach to discourse" (Keller, 2011) appears appropriate for reviewing the issue adequately. While in the first step of the analysis-which reflects upon the German migration regime-attention is given to linking general reflections (on discourses, knowledge, and practices) to findings gained primarily through an analysis of legal documents and statements, the second section-which addresses the struggle for recognition of Roma as well as justification narratives-offers research results that I obtained from observations and interviews, in particular.

Against this backdrop, I analyzed the practices of the protest movement as well as those of the German migration regime within the scope of multi-sited research (Marcus, 1995) carried out in multiple phases between 2012 and 2016 in numerous larger German cities. The sites were specially determined by participating in diverse demonstrations, political information and cultural events, as well as by maintaining (close) contact to Roma. In addition, I conducted interviews, including ones with Romani migrants, Romani representatives, (high ranking) politicians as well as various lawyers and NGO activists.

\section{On the Contemporary Human Rights Situation of Roma from the Western Balkans}

The primary reasons for the difficult human rights situation of Roma from the Western Balkans (but also from the Balkans in general) are not only due to a political shift to the right that began setting in with the collapse of communism/socialism. Such an explanation falls short: in order to grasp the dimension of the transformation process in the Western Balkans, one needs to take neoliberal developments into consideration. The promise of neoliberalism (e.g., prosperity for all) never materialized with the introduction of post-socialist states in the Balkans. Rather, it accelerated the division of these societies. With the onset of neoliberalism in the postsocialist Western Balkans, vehemently supported by the EU through its enlargement process, a new underprivileged class and a new form of poverty emerged. Not only are Roma affected, but they are situated on the lowest social rung, struggle the most with the already difficult living conditions, and are used as scapegoats for the adverse social and economic situation (Mappes-Niediek, 2012; van Baar, 2011a). 
While Roma de jure have the same rights as all other citizens of the respective states, they are de facto permanently denied these rights (Sardelić, 2015). According to Balibar (2003; 2009), the discrepancy between minorities' codified rights and rights in social practice cannot be resolved, as the current concepts of citizenship (particularly in the Balkans) are dominated by nationalism: a state for Roma that Balibar terms "European apartheid". Roma, who can at best be said to have semi-citizenship (Sardelić, 2016), are consequently exposed to a vicious cycle of structural discrimination whose individual components can scarcely be isolated: racism, high unemployment, ghettoization, poor institutionalized educational capital, almost nonexistent social mobility, lack of trust in (state) institutions, retreat towards kinship networks, etc. (Mappes-Niediek, 2012). ${ }^{7}$

Migration into foreign European countries then appears as a possibility to escape structural discrimination and claim fundamental human rights. How this migration occurs in each individual case, however, depends not only on the respective level of economic and social capital, but is also directly related to refugee policy and migration control in the EU, namely those of the respective destination states.

\section{Romani Migration and the German Migration Regime Within the European Context}

In the process of the Europeanization of migration control, the European Union has developed its own migration regime that has led to new and differentiated forms of securitization. The harmonization of migration policy and migration law within the EU has also brought about the consequence that not only external European borders, but also neighboring countries (as transit countries and the migrants' countries of origins) have become subject to migration control and have since been requested to assist the EU in selecting and regulating migrants (Banse, Müller, \& Stobbe, 2007; Betts, 2010). In this process, the EU established a cordon sanitaire around its territorial borders starting in the 1990s, through which it includes states into its political economy as needed and grants these states' citizens certain mobility rights (Andrijašević et al., 2005; Hess, 2012).

In reaction to the increasing numbers of migrants from the Western Balkans, the German government, as a constitutive and constituent part of the EU, began successively institutionalizing diverse legal measures in order to regulate the migration movement and carry out deportations more efficiently in 2009 (Heuser, 2014; Paech, 2016). However, since the arrival of large numbers of refugees in Germany in 2015, ${ }^{8}$ the German government reacted with the extreme tightening of asylum and refugee law in multiple steps (Wenke et al., 2016), which, in addition to the "asylum comprise" in 1993 (Cremer, 2013), can be considered the largest encroachment on refugee protection in German post-war history. ${ }^{9}$ In order to relieve authorities and courts of asylum procedures in terms of time and money, the German government, as part of Asylum Package 2, classified Kosovo, Montenegro, and Albania as "safe countries of origin"10 and thus declared them as "free from persecution" (Deutscher Bundestag, 2015a; Wissenschaftliche Dienste des Deutschen Bundestages, 2016).

Within this context, the Federal Office for Migration and Refugees (Bundesamt für Migration und Flüchtlinge) codes the migration of Roma as economically motivated, and thus they do not qualify for asylum or refugee protection. With this classification, the legislation creates a blanket presumptive rule of non-persecution, resulting in asylum seekers being required to present even more convincing and coherent persecution stories in order to be recognized as legitimate refugees. Unless those seeking protection do not assert facts satisfying the conclusion that they have been persecuted against this presumptive rule, they will receive a negative decision (Paech, 2016, p. 13ff).

The increasing number of Roma who migrated to Germany or other European member states beginning in 2009 can be explained in the context of visa exemption for citizens of the Western Balkans, whereby this is again closely related to a process that Kacarska (2012) labels as "Europeanisation through mobility". Whereas (most) Western Balkan states have already received visa liberalization (within the Schengen Area) in the long-term, ${ }^{11}$ they still only have the prospect of EU membership, ${ }^{12}$ also conditional on their protection of minorities. Nevertheless, the EU encourages the respective states to neglect human rights standards in order to more effectively reduce the number of asylum seekers (Flüchtlingsrat NRW, 2012).

In this context and using the example of negotiations between the German, Serbian, and Macedonian governments, lawyer Nizaqete Bislimi (2014) demonstrates how, in the process of visa liberalization, they had to perform numerous administrative reforms in return

\footnotetext{
${ }^{7}$ For a detailed overview, see European Roma Rights Centre (2016).

${ }^{8}$ According to the Federal Ministry of the Interior (Bundesministerium des Innern, 2016), approximately 890,000 people seeking protection were registered in 2015, notably refugees from Syria, Afghanistan, and Iraq.

${ }^{9}$ The Asylum Packages 1 and 2, passed by the Bundestag in 2015, constitute the spearhead of this development. In addition to declaring "safe countries of origins" and expediting the asylum process, the laws are accompanied particularly by restrictive work bans, unannounced deportations, deportations of those with serious illness, benefit cuts, tightening of family reunification processes, as well as an increase of integration courses, see Pro Asyl (2015a, 2015b).

10 The German government already classified Serbia, Bosnia and Herzegovina, and Macedonia as safe in 2014. Cf. Deutscher Bundestag (2014).

${ }^{11}$ Citizens of Serbia, Macedonia, Albania, Montenegro, and Bosnia and Herzegovina received visa exemption between 2008 and 2010 , which enabled them to move within the Schengen Area for a limited time (Kacarska, 2012). Such visa exemptions have yet to be granted for citizens of Kosovo. Cf. European Parliament (2017).

12 Not including Croatia, as it already became an EU member state in 2013.
} 
-including drafting bilateral readmission agreements that came into effect in 2002 and facilitating deportations of war refugees obligated to leave. ${ }^{13}$ With visa exemption in 2009 and the accompanying increase of asylum applications by Roma in Germany and other EU member states, the former German Federal Minister of the Interior, Hans-Peter Friedrich, as well as the EU Commission threatened the Serbian and Macedonian governments with reinstating visa requirements as long as the rising number of asylum applications did not stop. In the course of this, Friedrich approached the press and defamed migrants from Serbia and Macedonia as poverty migrants - targeting especially Roma even if only through implicit semantic references (Heuser, 2014, p. 71; see also Flüchtlingsrat NRW, 2012; Lee, 2014).

To divert attention from the social issue of the critical human rights situation, for instance, in Serbia in 2012, not only the media, but also the then Minister of Internal Affairs, Ivica Dačić, labeled Romani refugees as "false asylum seekers", migrating to Germany in order to leech off the German welfare state. In order to prevent Roma, who are not legally permitted to do so, from departing to Germany, ${ }^{14}$ border practices have emerged that represent "ethnic profiling", which is a violation of the European Convention of Human Rights (Flüchtlingsrat NRW, 2012). ${ }^{15}$ Due to the overall precarious human rights situation, a large part of Roma avoid deportation-which in the course of the Europeanization of migration policy is increasingly coordinated by the Frontières Exterieures (FRONTEX) - by escaping into "illegality" before deportation is enforced or by leaving the Western Balkans again after deportation (see e.g. Deutscher Bundestag, 2015b).

Against this overall backdrop, particularly the classification of Western Balkan states as safe countries of origin has been disputed: Paech criticizes the classification by stating that German legislation has not fulfilled the requirements for the careful examination of potentially safe countries of origin imposed by the Federal Constitutional Court. Paech therefore submitted a constitutional challenge, as he considers the legislation on the classification "unconstitutional" (Paech, 2015). Numerous studies by, for instance, the United Nations Children's Fund (UNICEF, 2012), arrive at a similarly critical classification of the Western Balkans that considers the situation of Roma, when seen in its entirety, to constitute "structural discrimination" (see also Paech, 2016, p. 14).

Criticism from the perspective of EU law relates to the latter point. According to European Parliament and European Council (2011), persecution is also present when there is "an accumulation of various measures, including violations of human rights, which is sufficiently severe as to affect an individual in a similar manner as mentioned in point". In order to claim cumulative infringements as a serious violation of human rights at the state level, Scherr (2015b, p. 161ff) indicates that a normatively coherent implementation is required. In practice, however, the imprecise formulation of the article means that this implementation ends up being disadvantageous to the refugees. He qualifies this open-ended formulation at the European level as not only "legally insufficient", but also "politically functional", as it serves to attenuate political controversy at the state level and redirect "moral responsibility" to the juridical field.

Based on the aforementioned points, it is evident that the term "refugee" not only functions as a legal category with which the respective receiving states classify the migration of people according to determined criteria, but also shows to what extent the receiving states politically and legally code the countries of origin (Nieswand, 2015). Nevertheless, at which point persecution and suffering becomes relevant to gaining asylum status remains an issue that is both in need of explanation and highly controversial in practice. As the migration of Roma usually arises as a mixed migration movement (read: a mixture of social, political, and economic reasons for migration) (Castañeda, 2014) and as these complex and interlocking connections are not fully reflected in the categories of German asylum and refugee law, an appropriate political and legal process of distinguishing between recognition and rejection of refugee status does not exactly become any easier. By classifying the Romani migration and thereby coding them as irregular migrants, however, German legislation has not only created legal facts, but also confirmed mainstream public media discourse in which Roma are a priori considered poverty migrants and accused of asylum abuse. Politics, law, and the media thereby not only contribute to further criminalization of migration, but reinforce and recreate stereotypes as well. Such attitudes, which Heuser (2014) frames as "anti-Romani racism", both stand in the way of an impartial public media appraisal of the human rights situation and structure the political and legal patterns of meaning (see also Lee, 2014).

\section{Struggle for Recognition of Romani Migrants: Translation of Human Rights}

In regard to the struggle for recognition, particularly active at the federal level are the Romani initiative "Alle bleiben" ("Everyone Stays") and the "Bundes Roma Verband" (BRV, "Federal Romani Association") as well as "Romano Jekipe ano Hamburg" ("United Roma in Hamburg"), "Initiative Rromnja" (Berlin), "Roma Center Göttingen e.V.", "Roma-Art-Action" (Essen), "Aktion 302/GGUA" (Munster), and "Rom e.V." (Cologne) at the regional or communal level. These (partly) wellnetworked "grassroots" organizations are (directly or indirectly) aided by numerous interest groups advocating

\footnotetext{
13 Between the EU and the Western Balkans, readmission agreements entered into force from 2007 (respectively, in the case of Albania, in 2005). Cf. Migrationsrecht.net (2007).

14 The right to depart requires certain criteria to be met, including monetary reserves, declarations, travel insurance, etc.

15 Current developments in the Western Balkans (except Croatia) again show that their EU accession process is at a standstill. This is due, on the one hand, in particular, to the unclear perspective of joining the EU and, on the other hand, to flourishing nationalism. Cf. Milačić (2017).
} 
on their behalf, such as political associations, church associations, or NGOs. These include not just the "usual suspects", for example leftist or refugee organizations, but also institutions located at the EU- and UN-level.

When I now sketch out the practices of translation and appropriation, which gain validity within the struggles, I assume, following Gephart (2015), that Romani migrants and their representatives are intertwining universal codes of human rights and legal-cultural practices. In the course of this, they reinterpret the actual jurisdiction, produce new rights, and enforce legal claims in form of justification narratives. The translation of justification narratives into the political-legal fields thus comes to the fore in two disparate ways. On the one hand, this occurs as strategic essentialism in which particular cultural traits and identifications are essentialized and politicized (Spivak, 1988). On the other hand, certain justification narratives are expressed as strategic universalism in which general norms and values, such as democracy, solidarity, and integration, are referenced (Gilroy, 2000). Based on my empirical analyses, I have identified six justification narratives that apply to differing extents depending on the spatial and temporal context and are intended to lead to a successful normative linking with current asylum or refugee law, in particular:

a) According to trustworthy estimates, approximately 500,000 people persecuted as "gypsies" fell victim to the atrocities in Europe carried out by the Nazis (Wissenschaftliche Dienste des Deutschen Bundestages, 2009, p. 10). In the course of reappraising the genocide and history of injustice during the Third Reich, appeals have been made to Germany's historical responsibility towards Roma from the Western Balkans, as no adequate compensation has been made so far. ${ }^{16}$ By relating their history to that of Jews, Roma latch on to the universalization process of the Holocaust as a relatively new form of normativity and link transnational memorial structures with legalmoral claims. ${ }^{17}$

b) The next justification narrative also relates to the Holocaust as a universal norm, but in a decontextualized manner. In 1999, the Holocaust served as a legitimization figure for an offensive NATO war in Kosovo (Wallerstein, 2006). The European Roma Rights Centre (2001), for example, spoke of the biggest catastrophe for Roma since World War II-first directly through the bombardments and then through the subsequent retalia- tory attacks through Kosovar troops who caused a mass exodus throughout Europe. Since the German government at the time was co-responsible for both the need to relocate and the destruction of the cultural livelihood of Roma, the narrative thus argues that the current German government bears responsibility here, too. ${ }^{18}$

c) The following narrative comprises the category "integration" as a domestic political code. In contrast to the previous two narratives, this one should not be interpreted as strategic essentialism, but rather as strategic universalism, as no differences, but instead shared democratic values are articulated here. Various Romani organizations and their supporters point to feats of integration and, rooted in this context, particularly those for Romani children born and raised in Germany. ${ }^{19}$

d) A further justification narrative refers to the legal order of the EU. Proponents of a right of residence argue that the Geneva Convention on Refugees should be interpreted more generously, namely in the way it is fixated in the Qualification Directive of the European Parliament and European Council (2011), which argues that structural discrimination should also find increasing recognition as a reason for seeking refuge. ${ }^{20}$

e) Another narrative is targeted at the classification of the Western Balkan states as safe countries of origin. This classification is not regarded as an objective situational assessment, but rather as a consideration implicitly aimed at preventing the entry of Roma that leads to an unreasonable distinction between legitimate refugees and poverty migrants. ${ }^{21}$

f) The last justification narrative draws a connection beyond the cultural context towards a larger democratic and whole-societal level. Since the resistance is aimed against the further hollowing-out of civilizational feats, these struggles serve democracy. Asylum law, according to the argument, is a suitable field of experimentation for future legal standards, as bio-political scenarios can be tested with irregularized migrants or refugees and then also be extended to other marginalized or precarious groups as needed, such as the unemployed. ${ }^{22}$

Following this outline of the different justification narratives, I shall conclude by elaborating on the occupation of the Memorial by "Romano Jekipe ano Hamburg" in cooperation with the German nationwide initiative "Alle

\footnotetext{
16 See, for example, author's interview with a former federal minister, Büdingen (2016); Romani representatives, Cologne (2015).

17 For general information on the topic "Universalization process of the Holocaust", see Alexander (2012).

18 See, for example, author's interview with Romani representative, Cologne (2015), field note in the context of a political event, Frankfurt (2016).

19 See, for example, author's interview with Romani migrants, Cologne (2012), Munster (2012), Berlin (2016); Bonn (2016); former human rights representative of the German government, Munster (2016), representative in European Parliament, Bonn-Strasbourg (Phone Interview) (2016).

20 See, for example, author's interview with Romani representative, Hamburg (2016); field notes in the context of political events with the participation of Romani representatives and civil society organizations, Cologne (2015), Berlin (2016).

21 See, for example, author's interview with Romani representative, Hamburg (2016); Romani migrants, Berlin (2016).

22 See, for example, author's field notes in the context of political events with the participation of Romani representatives and civil society organizations, Munster (2016) and Frankfurt (2016).
} 
bleiben", as this example illustrates both the intertwining of justification narratives and forms of mobilizing protest participants. Further, conflict lines between the occupants and other organizations can be shown, which in essence surround the question of a legitimate translation of human rights claims as well as the appropriate interpretation and various appropriation of historical symbols and memory.

\section{Forms of Struggles for Recognition: The Case of the Memorial of the Sinti and Roma in 2016}

On May 22, 2016, a group of approximately 50 Roma from Hamburg and Kiel, led by "Romano Jekipe ano Hamburg" and "Alle bleiben", occupied the Memorial to the Sinti and Roma Victims of National Socialism in Berlin. The Memorial was opened in 2012 following several political debates since the late 1980s. The fact that the massive and systematic murder of those persecuted as gypsies under the Third Reich was recognized as genocide by Federal Chancellor Helmut Schmidt in 1982 can be attributed to an earlier well-organized civil rights movement by German Sinti and Roma, with the activist Romani Rose leading the way (Schulze, 2010; van Baar, 2015).

According to Rose (2012), the Chairman of the "Central Council of German Sinti and Roma", the Memorial's political-remembrance relevance exists not only in commemorating the genocide, but also in combating contemporary and future forms of "antiziganism" and "antisemitism". ${ }^{23}$ Although Rose considers the current discrimination and persecution both a German and European challenge, the Central Council, the strongest political representative of the German minority, views its task primarily as representing, securing, and claiming the rights of German Sinti and Roma. The occupants again build on strategies that can be labeled as the "Europeanization of Roma representation" (van Baar, 2015). The "Europeanization of Roma representation" was employed most recently in the eastward expansion of the EU, whereby the EU did not see the Roma's living situation (here as an umbrella term) to be in line with general human rights. As a result, this was defined as a "European problem" that needed to be solved via legislative measures and (development) projects (van Baar, 2011a). By drawing on the European representation form and the symbolism that emanates from the Memorial and connecting the two as well as the German state's view of its historic responsibility to do justice to all European Roma, especially those from the Western Balkans, they are hoping for an extension of current German asylum and refugee protection in the form of residence rights. How this takes place and which justification narratives thereby come into play will be explained in the following sections.

No longer feeling solidarity and disappointed by politicians, the occupants considered the Memorial an appropriate place to make a political statement against deportations and raise awareness for the human rights situation, according to a Romani representative from the initiative "Alle bleiben" and the "Bundes Roma Verband". ${ }^{24}$ The classification of the Western Balkans as safe countries of origin, in particular, is viewed as a consequential misinterpretation and an abolishment of asylum law. As the Romani representative of "Romano Jekipe ano Hamburg" formulated: "These states may be safe, but not for Roma". Against this background, the representative demanded a halt to deportations and a right of residence on humanitarian grounds. In this context, he also pointed to Germany's historical responsibility, adding that he could not comprehend the hierarchization of victims by the German government. He thereby criticized the preference given to the fate of Jews and called for "compensation", which neither his grandparents nor he had received. The case of Jewish contingent refugees who obtained a humanitarian right of residence in the early 1990s shows that such a justification narrative can lead to a right of residence. ${ }^{25}$

With these arguments, the protest participants from Hamburg and Kiel could also be mobilized. Since they are subject to compulsory residence, not only their travel to Berlin, but also the unannounced occupation placed their already fragile status in jeopardy. According to a Romani migrant who participated in the occupation, the initiators' justification was convincing even though the actions constituted criminal offenses according to German law. The significance of the Memorial, which they had previously not rated so highly, aroused hope in them that they could, in fact, still receive right of residence during the occupation. ${ }^{26}$ Further, the organizations enjoyed the trust of the protest participants, a Romani representative of "Romano Jekipe ano Hamburg" maintained, as they had gained knowledge about resistance over many years of political activity. This knowledge was acquired through networking with other Romani and refugee organizations. ${ }^{27}$

While the occupation, according to a Romani representative of "Alle bleiben", garnered great media attention, it did not lead to the desired success, as riot police vacated the premises after an unresolved conflict between the occupants and the property owners, the "Foundation Memorial to the Murdered Jews of Europe". ${ }^{28}$ The eviction did occur, however, in consultation

\footnotetext{
23 The significance of the location of the Memorial is thus strengthened as it is directly beside the Reichstag and close to Brandenburg Gate and the Memorial to the Murdered Jews of Europe. For more on the political-remembrance significance of the Memorial, see van Baar (2015).

24 Author's interview with Romani representative of "Alle bleiben" and the "Bundes Roma Verband", Berlin (2016); see also field notes in the context of political event, Frankfurt (2016).

25 Author's interview with Romani representative of “Romano Jekipe ano Hamburg”, Hamburg (2016).

${ }^{26}$ Author's interview with Romani migrant, Berlin (2016).

27 Author's interview with Romani representative of Romano Jekipe ano Hamburg, Hamburg (2016).

28 Author's interview with Romani representative of "Alle bleiben" and the "Bundes Roma Verband", Berlin (2016).
} 
with the "Central Council of German Sinti and Roma", "Roma Trial", and high ranking politicians of the Green Party and the President of the German Parliament-who demonstrated solidarity with the protesters, but nevertheless legitimated the eviction with the argument that the dignity of the place had been compromised by the protest action (Stiftung Denkmal für die ermordeten Juden Europas, 2016). ${ }^{29}$

Whereas the occupiers interpreted the Memorial as the one place where their demands could still be heard due to its sacral symbolism, the property owners and their supporters had a different stance. While they, too, viewed the Memorial as a sacred place, they considered political protests there tantamount to sacrilege, as the murdered had found their final resting place there (Stiftung Denkmal für die ermordeten Juden Europas, 2016). ${ }^{30}$ "Alle bleiben" (2016) countered that the eviction by a police unit itself should be considered a practice that was both political and based on violence. They accused the foundation of reserving the right for political actions on their own premises, while denying this right to protesters. They further reproached the property owners and their supporters of a failing, formulated in a commentary as follows: "What happened last night in Berlin is a demonstration of the inability of the powerful to face the suffering of Roma moved to and fro for decades" (own translation). Next to the social problem of constant human rights violations committed against Roma, a conflict concerning the legitimate interpretation of the past and its symbols can be detected here as well. In this regard, "Alle bleiben" raises the question: "Where does remembrance end and where does politics begin -and who decides?"

Shortly following the occupation, the foundation convened at a round table in the "Sicherheitstrakt" (roughly: "security wing") of the "Memorial to the Murdered Jews of Europe" (Berlin) in order to find a solution to the residence law situation of the Romani migrants. While several established politicians participated at the round table-including members from Green and Left Parties as well as a subordinate of the Minister of State and a former Federal Minister on the governmental side — "Romano Jekipe ano Hamburg" or "Alle bleiben" were not invited. The only Romani representative was from "Roma Trail", who sided with the property owners during the occupation. While the round table was not a governmental institution and the participants therefore had no direct influence on the residence law situation of Roma, their professions meant that the participants were well networked and influential. ${ }^{31}$

However, the participants of the round table came to the assessment that the demands to revoke the classification of the Western Balkan states as safe countries of origin, establish a quota solution, and secure an unrestricted right of residence did not represent realistic options that could be plead for to the German federal government. Rather, considering the political developments in Germany (see, for instance, the "refugee crisis" and the electoral victories of the right-wing party "AfD"), a pragmatic solution should be targeted. Given the tense public media discourse surrounding refugees, however, one could not carry out the demands for right of residence in public, but rather behind the scenes in the form of lobbying efforts or legal practice. ${ }^{32}$

The analysis of the occupation could show that while the actors involved have the same goal, namely right of residence for Romani migrants, they prefer other strategies for the ensuring of human rights. Whereas the round table did not give consideration to the demand for a collective right of residence but "merely" advocated lobbying and stronger efforts in individual cases, ${ }^{33}$ "Alle bleiben" and the "Bundes Roma Verband" insist on a humanitarian right of residence and are attempting to succeed in this goal through a petition and further political activities. ${ }^{34}$ In addition, it was also shown that the Memorial's symbolism is interpreted against the background of cultural application filters, whereby the thus involved conflict presents a struggle for the legitimate representation of political resistance in the face of the German migration regime.

\section{Conclusion}

Factually seen, the human rights claims for a collective right of residence for Romani migrants is misconceived and distorted by the German federal government. A quote from the former Minister of the Interior, Wolfgang Schäuble (2007), clearly illustrates this situation, notwithstanding the fact that it already dates back a decade: "But first it is not possible to treat Roma and Sinti differently than other foreigners with the same status in this manner, for that would amount to positive discrimination" (own translation). In other words: Once Romani migrants apply for asylum or receive a Duldung (temporary suspension of deportation), thereby applying for a state decision, the remainder of the process is then also legally carried out according to this logic. The moral responsibility that follows the question of affiliation of Romani migrants is consequentially rejected by German policy and is redirected to asylum and refugee law, in the course of which the majority of protection claims are denied.

At the same time, the German government is attempting to steer the migration of Roma from the Western Balkans by embedding this in their political economy. Given the increasing number of asylum seekers from

\footnotetext{
29 See also author's interview with civil society organization representative, Berlin (2016).

30 See also author's interview with civil society organization representative, Berlin (2016).

31 Author's interview with civil society organization representative, Berlin (2016).

32 Ibid.

33 Ibid.

${ }^{34}$ Field notes in the context of political event, Berlin (2016).
} 
the Western Balkans in the year 2015, the federal government slightly opened the migration corridor in accordance with legal measures. However, especially trainees, highly-qualified persons as well as professionals, whose longer stays were made possible through strongly regulated work visas, benefit from this. Within these measures, an incentive for asylum seekers to voluntarily leave Germany and demand a work visa in their countries of origin, which would enable a stable residence, should simultaneously be created. Aside from the fact that many work visa applications fail due to bureaucratic hurdles (Deutscher Bundestag, 2017), the economization of immigration law diametrically opposes the protest movement's demands for human rights.

In the overall context, the negative decisions and deportations are in turn culturalized by the protest movement and are recalled as a further episode in the history of rights infringements or even as an "anti-Roma" legal state. In the course of this, human rights, however, are no neutral topos. On the contrary, the Romani protest movement has appropriated the power of human rights to the extent that it strategically makes use of the objection in order to exert normative pressure on state institutions. Romani and refugee organizations, in particular, repeatedly demonstrate new and creative ways to problematize practices of the German migration regime and produce new human rights semantics. They make their efforts visible in form of counter de-politicization of irregularized migrants, and, last but not least, justification narratives. Within these narratives, strategic essentialism and universalism are not to be understood as antagonisms, but rather as necessary forms of representation that interact with each other in order for Roma to become visible as a collective. In the "name of culture" (Gephart, 2012, p. 43), together with its inherent universal human rights norms, they thus convey belonging to the German nation-state. Nevertheless, the occupation of the Memorial has demonstrated that differing translation and appropriation throughout the legal struggles can lead to (inner) conflicts, which in this case resulted in a further differentiation of the protest movement.

By analyzing additional cases, the connection among Romani "grassroots" organizations and non-Romani organizations could be shown in more detail as could the concrete knowledge translated between them and the forms associated with reciprocal politicization. From a more comparative perspective, there are still questions concerning Romani migrants' relationship to Romani organizations, on the one hand, as well as to non-Romani organizations, on the other. This approach could also shed light on how different modi operandi of the appropriation and translation of human rights within the struggle for recognition become visible.

\section{Acknowledgments}

I would like to thank all interview partners. I also want to thank the editors of this issue for giving me the oppor- tunity to publishing the article, António Vieira from Social Inclusion for his professional cooperation during the editing process, the anonymous reviewers for their useful comments on an earlier version of this article, Candice Kerestan and Johannes Winckelmann for their English proofreading of the manuscript, as well as Daniel Witte for his valuable content-related feedback.

\section{Conflict of Interests}

The author declares no conflict of interests.

\section{References}

Alexander, J. (2012). Trauma: A social theory. Cambridge: Polity Press.

Alle bleiben. (2016). Das Denkmal für die ermordeten Roma und Sinti Europas in Berlin. Alle bleiben. Retrieved from http://www.alle-bleiben.info/das-denk mal-fur-die-ermordeten-roma-und-sinti-europas-inberlin-kein-platz-fur-politischen-protest-platz-fur-po lizeieinsatz

Alscher, S., Obergfell, J., \& Roos, S. R. (2015). Migrationsprofil Westbalkan. Ursachen, Herausforderungen und Lösungsansätze. Nürnberg: Bundesamt für Migration und Flüchtlinge.

Andrijašević, R., Bojadžijev, M., Hess, S., Karakayali, S., Panagiotidis, E., \& Tsianos, V. (2005). Turbulente Ränder. Konturen eines neuen Migrationsregimes im Südosten Europas. PROKLA. Zeitschrift für kritische Sozialwissenschaft, 35(3), 345-362.

Balibar, É. (2003). We, the people of Europe? Reflections on transnational citizenship. Princeton: Princeton University Press.

Balibar, É. (2009). Foreword. In N. Sigona \& N. Trehan (Eds.), Romani politics in contemporary Europe (pp. viii-xiii). Basingstoke: Palgrave Macmillan UK.

Banse, C., Müller, D., \& Stobbe, H. (2007). Ungleiche Partner Migrationsmanagement in der Europäischen Nachbarschaftspolitik. iz3w, 302, 8-10.

Benhabib, S. (2004). The rights of others: Aliens, residents, and citizens. New York: Cambridge University Press.

Betts, A. (2010). The refugee regime complex. Refugee Survey Quarterly, 29(1), pp. 12-37.

Bislimi, N. (2014). Rrom_nja in Deutschland: Visumsfreiheit oder frei von Rechten? Heinrich Böll Stiftung. Retrieved from https://heimatkunde.boell.de/2014/ 12/03/rromnja-deutschland-visumsfreiheit-oder-frei -von-rechten\#_ftnref3

Bundesministerium des Innern. (2016). 890.000 Asylsuchende im Jahr 2015. Bundesministerium des Innern. Retrieved from http://www.bmi.bund.de/ SharedDocs/Pressemitteilungen/DE/2016/09/asylsu chende-2015.html

Çağlar, A., \& Mehling, S. (2013). Sites and the scales of the law: Third-country nationals and EU Roma citizens. In E. Isin \& M. Saward (Eds.), Enacting European cit- 
izenship (pp. 155-177). Cambridge: Cambridge University Press.

Castañeda, H. (2014). European mobilities or poverty migration? Discourses on Roma in Germany. International Migration, 53(3), 3-7.

Cherkezova, S. (2014). Potential Romani migrants from the Western Balkans. In European Roma Rights Centre (Ed.), Going nowhere? (pp. 5-14). Budapest: ERRC.

Cremer, H. (2013). Die Asyldebatte in Deutschland: 20 Jahre nach dem "Asylkompromiss". Berlin: Deutsches Institut für Menschenrechte.

Deutscher Bundestag. (2014). Gesetz zur Einstufung weiterer Staaten als sichere Herkunftsstaaten und zur Erleichterung des Arbeitsmarktzugangs für Asylbewerber und geduldete Ausländer vom 06. November 2014. Deutscher Bundestag. Retrieved from http://dipbt.bundestag.de/extrakt/ba/WP18/597/59 719.html

Deutscher Bundestag. (2015a). Asylverfahrensbeschleunigungsgesetz vom 20. Oktober 2015. Deutscher Bundestag. Retrieved from http://www.buzer.de/ gesetz/11736/index.htm

Deutscher Bundestag. (2015b). Stand der Abschiebungen in den Kosovo Ende 2014. Deutscher Bundestag. Retrieved from http://dip21.bundestag.de/ dip21/btd/18/043/1804398.pdf

Deutscher Bundestag. (2017). Arbeitsvisa für Menschen vom Westbalkan-Bilanz, Probleme, Perspektiven. Deutscher Bundestag. Retrieved from http:// dip21.bundestag.de/dip21/btd/18/111/1811124.pdf

European Parliament. (2017). Kosovo: Länderbericht 2016. European Parliament. Retrieved from http:// www.europarl.europa.eu/RegData/etudes/ATAG/20 17/603910/EPRS_ATA(2017)603910_DE.pdf

European Parliament, \& European Council (2011). Qualification Directive 2011/95/EU of 13 December 2011. EUR-Lex. Retrieved from http://eurlex.europa.eu/LexUriServ/LexUriServ.do?uri=OJ:L:20 11:337:0009:0026:en:PDF

European Roma Rights Centre. (2001). Roma in the Macedonian conflict. European Roma Rights Centre. Retrieved from http://www.errc.org/article/roma-inthe-macedonian-conflict/256

European Roma Rights Centre. (2016). Writing comments: EC submission on Roma inclusion in the Western Balkans. European Roma Rights Centre. Retrieved from http://www.errc.org/cms/upload/file/ec-sub mission-on-roma-inclusion-in-the-western-balkansjuly-2016.pdf

Flüchtlingsrat NRW. (Ed.). (2012). Die Liberalisierung des Visasystems und Einschränkung des Rechts auf Asyl. Flüchtlingsrat-Brandenburg. Retrieved from www.fluechtlingsrat-brandenburg.de/wp-content/up loads/2011/10/bericht-serbien1.pdf

Gephart, W. (2012). Für eine geisteswissenschaftliche Erforschung von Recht im Globalisierungsprozess. In W. Gephart (Ed.), Rechtsanalyse als Kulturforschung (pp. 19-53). Frankfurt am Main: Vittorio Klostermann.
Gephart, W. (2015). Einführung. Das "Recht als Kultur"Paradigma. In W. Gephart \& J. C. Suntrup (Eds.), Rechtsanalyse als Kulturforschung II (pp. 7-16). Frankfurt am Main: Vittorio Klostermann.

Gilroy, P. (2000). Against race: Imagining political culture beyond the color line. Cambridge, MA.: Harvard University Press.

Göhlich, M., Nekula, M., Renn, J. (2014). Übersetzungszwänge grenzüberschreitender Organisationen und die Relevanz geisteswissenschaftlicher Expertise. In N. Engel, M. Göhlich, T. Höhne, M. Klemm, C. Kraetsch, C. Marx, ... \& \& J. Renn (Eds.), Grenzen der Grenzüberschreitung (pp. 9-18). Bielefeld: transcript Verlag.

Hancock, I. F. (2002). We are the Romani people = Ame sam e Rromane džene. Hatfield: University of Hertfordshire Press.

Hess, S. (2012). Gefangen in der Mobilität. Prekäre Zonierungsprozesse an den Rändern Europas. Behemoth, 5(1), 8-29.

Hess, S., \& Karakayali, S. (2007). New Governance oder Die imperiale Kunst des Regierens. Asyldiskurs und Menschenrechtsdispositiv im neuen EU-Migrationsmanagement. In TRANSIT MIGRATION Forschungsgruppe (Eds.), Turbulente Ränder (pp. 41-59). Bielefeld: transcript Verlag.

Heuser, H. (2014). Blitzverfahren: German asylum procedures for Roma from Western Balkan Countries. In European Roma Rights Centre (Ed.), Going nowhere? (pp. 71-78). Budapest: ERRC.

Kacarska, S. (2012). Europeanisation through mobility: Visa liberalisation and citizenship regimes in Western Balkans. CITSEE Working Paper no. 2012/21. Edinburgh: University of Edinburgh.

Karakayali, S., \& Tsianos, V. (2007). Movements that matter. Eine Einleitung. In TRANSIT MIGRATION Forschungsgruppe (Eds.), Turbulente Ränder (pp. 7-22). Bielefeld: transcript Verlag.

Keller, R. (2011). Wissenssoziologische Diskursanalyse. Grundlegung eines Forschungsprogramms. Wiesbaden: VS Verlag.

Knecht, M., \& Toivanen, R. (2006). Einleitung: Roma Ethnographie, Anthropologie der Menschenrechte, Europäisierungsprozesse-Ein Plädoyer für Verbindungen. In R. Toivanen \& M. Knecht (Eds.), Europäische Roma-Roma in Europa (pp. 7-19). Münster: LIT Verlag.

Lee, C. E. (2014). Counting on confusion: Romani asylumseekers in the German media, 2012-2013. In European Roma Rights Centre (Ed.), Going nowhere? (pp. 79-86). Budapest: ERRC.

Mappes-Niediek, N. (2012). Arme Roma, böse Zigeuner: Was an den Vorurteilen über die Zuwanderer stimmt. Berlin: Ch. Links Verlag.

Marcus, G. A. (1995). Ethnography in/of the world system: The emergence of multi-sited ethnography. Annual Review of Anthropology, 24, 95-117.

Migrationsrecht.net (2007). EU: Rückübernahme- 
abkommen mit den Westbalkanländern. Migrationsrecht.net. Retrieved from http://www.migration srecht.net/nachrichten-auslaenderrecht-europa-und -eu/1153-eu-rbernahmeabkommen-serbien-bosnien -albanien-mazedonien.html

Milačić, F. (2017). Tanz auf dem Balkan. Politiker spielen im Westbalkan mit Nationalismus und reden über Krieg, auch weil eine klare EU-Beitrittsperspektive fehlt. Internationale Politik und Gesellschaft. Retrieved from http://www.ipg-journal.de/kommen tar/artikel/tanz-auf-dem-balkan-2109

Müller, D. (2010). Flucht und Asyl in europäischen Migrationsregimen. Göttingen: Univ.-Verl. Göttingen.

Nieswand, B. (2015). "Flüchtlinge" als Kategorie zur rechtlichen Strukturierung des Grenz- und Zuwanderungsregimes. Interview conducted by M. Krüger. Soziologieblog. Retrieved from http://soziologieblog. hypotheses.org/8909

Paech, N. (2015). Gutachten zur Verfassungsmäßigkeit des "Gesetzes zur Einstufung weiterer Staaten als sichere Herkunftsstaaten und zur Erleichterung des Arbeitsmarktzugangs für Asylbewerber und geduldete Ausländer" vom 06. November 2014. Pro Asyl. Retrieved from https://www.proasyl.de/fach newsletter-beitrag/rechtsgutachten-zur-verfassungs maessigkeit-der-seit-2014-angeblich-sicheren-herkun ftslaender-im-westbalkan

Paech, N. (2016). Why do "safe countries of origin" contradict the fundamental right to asylum? In RosaLuxemburg-Stiftung Southeast Europe (Ed.), Not safe at all (pp. 11-18). Belgrad: Rosa Luxemburg Stiftung Southeast Europe.

Pro Asyl. (2015a). Asylpaket I in Kraft: Überblick über die ab heute geltenden asylrechtlichen Änderungen. Pro Asyl. Retrieved from https://www.proasyl.de/hinter grund/asylpaket-i-in-kraft-ueberblick-ueber-die-abheute-geltenden-asylrechtlichen-aenderungen

Pro Asyl. (2015b). "Asylpaket II": Frontalangriff auf das individuelle Asylrecht. Pro Asyl. Retrieved from https://www.proasyl.de/news/asylpaket-ii-frontalan griff-auf-das-individuelle-asylrecht

Renn, J. (2010). Koordination durch Übersetzung, die Ordnungsfrage aus der Perspektive einer pragmatistischen Gesellschaftstheorie. In S. Sigmund \& G. Albert (Eds.), Soziologische Theorien (pp. 311-328). Wiesbaden: VS Verlag.

Rose, R. (2012). Denkmal für die im Nationalsozialismus ermordeten Sinti und Roma Europas Rede zur Einweihung des Denkmals in Berlin am 24. Oktober 2012. Zentralrat Deutscher Sinti und Roma. Retrieved from http://zentralrat.sintiundroma.de/wpcontent/uploads/2016/03/Rede_Rose.pdf

Sardelić, J. (2014). Romani minorities and the variety of migration patterns in the post-Yugoslav space. In European Roma Rights Centre (Ed.), Going nowhere? (pp. 15-22). Budapest: ERRC.

Sardelić, J. (2015). Romani minorities and uneven citizenship access in the post-Yugoslav space. Ethnopolitics,
14(2), pp. 159-179.

Sardelić, J. (2016). The position and agency of the 'irregularized': Romani migrants as European semicitizens. Politics. Retrieved from http://journals.sage pub.com/doi/abs/10.1177/0263395716668537

Schäuble, W. (2007). Roma und Sinti in Deutschland und Europa. Bundesministerium des Innern. Retrieved from http://www.bmi.bund.de/SharedDocs/ Reden/DE/2007/03/bm_roma_und_sinti_in_d.html

Scherr, A. (2015a). Armutsmigranten oder Flüchtlinge? Soziologische Kritik einer folgenreichen Unterscheidung am Fall von Roma aus dem Kosovo und Serbien. Deutsche Gesellschaft für Soziologie. Retrieved from http://publikationen.soziologie.de/index.php/ kongressband_2014/issue/view/8

Scherr, A. (2015b). Wer soll deportiert werden? Wie die folgenreiche Unterscheidung zwischen den "wirklichen" Flüchtlingen, den zu Duldenden und den Abzuschiebenden hergestellt wird. Soziale Probleme, 26(2), 151-170.

Schulze, R. (Ed.). (2010). The Porrajmos: The "Gypsy Holocaust" and the continuing discrimination of Roma and Sinti after 1945. Colchester: University of Essex.

Sigona, N., \& Trehan, N. (Eds.) (2009). Romani politics in contemporary Europe. Poverty, ethnic mobilization, and the neoliberal order. Basingstoke: Palgrave Macmillan UK.

Spivak, G. C. (1988). In other worlds. New York: Routledge.

Stammers, N. (2009). Human rights and social movements. London and New York: Pluto Press.

Stiftung Denkmal für die ermordeten Juden Europas. (2016). Pressemitteilung zur Besetzung des Denkmals für die im Nationalsozialismus ermordeten Sinti und Roma Europas aus Protest gegen drohende Abschiebung vom 23. Mai 2016. Stiftung Denkmal für die ermordeten Juden Europas. Retrieved from https://www.stiftung-denkmal.de/presse/pressemit teilungen/detail/article/besetzung-des-denkmals-fu er-die-im-nationalsozialismus-ermordeten-sinti-undroma-europas-aus-protest-gegen-drohende-abschie bung.html

Suntrup, J. (2013). Recht als Kultur. Ein blinder Fleck der politischen Kulturforschung. Zeitschrift für Politische Theorie, 4(2), 170-189.

Tremlett, A., McGarry, A., \& Agarin, T. (2014). The work of Sisyphus: Squaring the circle of Roma recognition. Ethnicities, 14(6), 727-736.

United Nations Children's Fund. (2012). Silent harm -A report assessing the situation of repatriated. UNICEF. Retrieved from www.unicef.org/kosovo programme/SILENT_HARM_Eng_Web.pdf

van Baar, H. J. M. (2011a). The European Roma: Minority representation, memory, and the limits of transnational governmentality (PhD Dissertation). Retrieved from https://pure.uva.nl/ws/files/1164494/ 98861_thesis.pdf

van Baar, H. J. M. (2011b). Europe's Romaphobia: 
Problematization, securitization, nomadization. Environment and Planning D- Society \& Space, 29(2), 203-212.

van Baar, H. J. M. (2015). Enacting memory and the hard labor of identity formation: Rethinking the Romani movement and its historiography. In A. McGarry \& J. Jasper (Eds.), The identity dilemma (pp. 150-169). Philadelphia: Temple University Press.

Wallerstein, I. (2006). European universalism: The rhetoric of power. New York: The New Press.

Wenke, C., Jadžić T. B., \& Jeremić, V. (2016). Introduction. In Rosa-Luxemburg-Stiftung Southeast Europe (Ed.), Not safe at all (pp. 5-10). Belgrad: Rosa Luxemburg
Stiftung Southeast Europe.

Wissenschaftliche Dienste des Deutschen Bundestages. (2009). Die Verfolgung der Sinti und Roma im Nationalsozialismus. Deutscher Bundestag. Retrieved from https://www.bundestag.de/blob/410880/917c712d 81cb4578775060ed6f592b2b/wd-1-020-09-pdf-data. pdf

Wissenschaftliche Dienste des Deutschen Bundestages. (2016). Rückführungsabkommen und sichere Herkunftsstaaten. Deutscher Bundestag. Retrieved from https://www.bundestag.de/blob/425092/f2131c7bb b5d77dbeda9b598cefe89e6/wd-3-064-16-pdf-data. pdf

\section{About the Author}

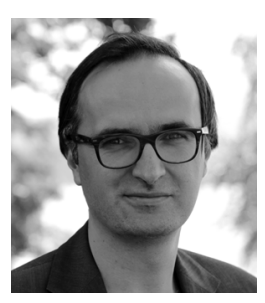

Jure Leko is a researcher at the Käte Hamburger Center for Advanced Study in the Humanities "Law as Culture". Focused on the fields of cultural anthropology and sociology, his work pursues questions of cultural theory, examining comparative and legal anthropology, as well as political sociology in the process. He is now working on his PhD thesis which concerns human rights and the legal struggles for recognition of Romani migrants. Furthermore, he is co-editor of the volume Law and the Arts. Elective Affinities and Relationships of Tension (conjointly with Werner Gephart). 